\title{
SULTAN TERNATE ISKANDAR DJABIR SYAH DAN PETUALANGANNYA DALAM NEGARA INDONESIA TIMUR, 1946-1950
}

\author{
Rustam Hasim ${ }^{1}$, Faisal ${ }^{2}$ dan Rasti Amalia Faruk ${ }^{3}$ \\ ${ }^{1}$ Dosen Prodi Pendidikan Pancasila dan Kewarganegaraan, FKIP Universitas Khairun, Jl. Bandara Baabullah Akehuda Ternate \\ Utara, 97728, Indonesia \\ ${ }^{2}$ Dosen Hukum Pidana, Fakultas Hukum Universitas Khairun, Jl. Jusuf Abdurrachman Gambesi Ternate Selatan, Indonesia \\ ${ }^{3}$ Dosen Hukum Tata Negara, Fakultas Hukum Universitas Khairun, Jl. Jusuf Abdurrachman Gambesi Ternate Selatan, \\ Indonesia
}

Author Correspondence: rustamhasyim@gmail.com

$\begin{array}{ll}\text { Diterima } & : 02-02-2018 . \\ \text { Direvisi } & : 10-03-2018 \\ \text { Dipublikasi } & : 05-04-2018\end{array}$

Abstract. This study aims to reconstruct the political participation of Iskandar Djabir Syah (the $47^{\text {th }}$ Sultan of Ternate) in the establishment of the State of Eastern Indonesia. The study focuses on outlining some political events involving Iskandar Djabir Syah such as the Malino and Denpasar conferences and becaming the Minister of Home Affairs of the Eastern Indonesia State for 1949 to 1950 periods. The method used in this paper is a heuristic method that is history, criticism, interpretation and historiography. The results showed that: (1) the participation of Sultan of Ternate Iskandar Djabir Syah in the unitary state started in the early independence of the Republic of Indonesia; it was characterized by conducting Malino and Denpasar conferences in 1946. The establishment of the Eastern Indonesia State became the political inspiration for Iskandar Djabir Syah to involve as the senate member of the Eastern Indonesia State/NIT representing North Maluku, as well as one of its designers. (2) As one of the leaders who agreed to the idea of van Mook to form a federalist country in the Malino and Denpasar conference, so that when the Eastern Indonesia State was formed, he was appointed as the Minister of Home Affairs in the cabinet of J.E. Tatengkeng for 1949 to 1950 periods. (3) Malino to Denpasar Conference in 1946 initiated by H.J. van Mook was the Dutch effort to establish the states in order to realize the United States of Indonesia (Republik Indonesia Serikat/RIS) based on Linggarjati Agreement. At the conference, it was formed the Eastern Indonesia State (Negara Indonesia Timur/NIT) covering the areas of Sulawesi, Small Sunda (Bali and Nusa Tenggara) and the Maluku Islands.

Keywords: Sultan of Ternate Iskandar Djabir Syah, Political History, Malino and Denpasar Conferences, the Minister of Home Affairs of Eastern Indonesia State (NIT).

\section{PENDAHULUAN}

Iskandar Djabir Syah adalah Sultan Ternate ke-47, dilahirkan di Ternate pada tanggal 4 Maret 1902. Iskandar Djabir Syah merupakan anak kedua dari tujuh bersaudara dari pasangan Hi. Usman Syah (Sultan Ternate ke-46) dan putri Mihir (bangsawan Susupu). Pendidikan formalnya dimulai pada tahun 1912 dengan memasuki Sekolah Melayu (Sekolah Dasar) di Ternate. Setelah tamat dari SD Melayu pada tahun 1915, ia melanjutkan ke Europese Lagere School (SMP) di Ternate, namun tidak tamat karena bersama ayahnya Sultan Usman di asingkan oleh Belanda ke Bandung karena dituduh terlibat pemberontakan di Jailolo (Halmahera Barat) pada 1914. Pada tahun 1917 Iskandar Djabir melanjutkan sekolahnya ke MULO di Batavia. Selama menimba ilmu di Batavia, banyak berteman dengan tokohtokoh pergerakan, salah satunya Agus Salim yang mengajaknya untuk bergabung dengan organisasi politik PSI pada tahun 1920-1925. Dari sinilah Iskandar Djabir Syah mengenal politik secara langsung sehingga mempengaruhi pemikiran politiknya di kemudian hari.

Kiprah politik Iskandar Djabir Syah pada pentas politik nasional, dimulai pada awal kemerdekaan Republik Indonesia. Sejarah menunjukkan partisipasi politik Iskandar Djabir Syah, ditandai dengan berdirinya Negara Indonesia Timur (NIT), pada tanggal 24 Desember 1946. Terbentuknya Negara Indonesia Timur kemudian menjadi inspirasi politik bagi Sultan Iskandar Muhammad Jabir Syah (Sultan Ternate ke-47), untuk melibatkan diri sebagai anggota senat NIT mewakili Maluku Utara, sekaligus merupakan salah satu desainernya. Pada periode tersebut Iskandar Djabir Syah mengambil 
sikap politik yang berbeda dengan Soekarno, dengan mengikuti konsep negara federal yang digagas oleh van Mook. Perbedaan persepsi mengenai bentuk dan sistem pemerintahan Indonesia pasca kemerdekaan yang akan menggantikan bentuk dan sistem pemerintahan kolonial Hindia Belanda merepresentasikan kedua kubu yang berbeda. Pandangan kaum nasionalis meyakini bahwa keutuhan Negara Indonesia adalah final dan merupakan kehendak suluruh rakyat Indonesia sebagaimana diamanatkan dalam UUD 1945. Sementara hal berbeda disampaikan Sultan Iskandar Djabir Syah, sebagai utusan yang mewakili Maluku Utara dalam konferensi Malino dan Denpasar 1946 mengenai pembentukan Negara Indonesia Timur. Menurut Iskandar Djabir Syah, bahwa pembentukan negara federal bukanlah disintegrasi tapi suatu sistem pemerintahan yang tidak berbeda dengan negara kesatuan. Ide dasar negara federal yang paling subtansial agar terjamin keadilan dalam alokasi sumber daya, disamping itu memungkinkan manajemen adiministrasi menjadi lebih efektif dan efisien, karena lingkupnya lebih terbatas. Di samping itu, Negara Indonesia Timur akan menjelma menjadi sebuah negara yang makmur dan dapat mengembangkan identitasnya sendiri, sebagaimana diinginkan semua pihak.

Sikap konfrontatif Iskandar Djabir Syah tersebut, mendorong Presiden Soekarno mengeluarkan sejumlah kebijakan dalam membatasi peran politik mereka, seperti; pertama, pembubaran dewan rajaraja (badan eksekutif), terdiri dari Sultan Ternate, Tidore dan Bacan dan Noord Molukken Raat (badan legislatif) yang mendukung federalisme pada tahun 1950. Konsekuesinya, elite kesultanan tidak lagi mempunyai instrumen legal-formal dalam mempengaruhi pemerintahan lokal. Kontrol mereka terhadap birokrasi kemudin digantikan oleh bupati yang dipilih oleh DPRD. Kedua, penghapusan Karesidenan Ternate dan pembentukan pemerintahan daerah tingkat II Maluku Utara, berdasarkan UU. No. 60 tahun 1958. Konsekuesinya penguasa di tingkat II (Bupati) tidak lagi harus dijabat oleh sultan dan keluarganya, tetapi dipilih melalui pemilu dalam format politik modern. Ketiga, lahirnya UndangUndang Pokok Agraria 1960 tentang pembatasan dan kepemilikan tanah atau pengambil alihan oleh negara terhadap tanah-tanah swapraja.

Ketika Negara Indonesia Serikat (RIS) bubar dan berganti menjadi Negara Kesatuan Republik Indonesia pada tanggal 17 Agustus 1950. Pemerintahan Presiden Soekarno mengasingkan Iskandar Muhammad Djabir Sjah ke Jakarta sebagai tahanan politik. Ia dituduh sebagai salah satu tokoh federal. Selama di Jakarta, ia ditempatkan sebagai salah satu pegawai Departemen Dalam Negeri sejak tahun 1951, hingga wafat pada 1975. Selama pengasingannya di Jakarta, kesultanan Ternate mengalami kekosongan pemerintahan. Seluruh kegiatan dan pelaksanaan pemerintahan dijalankan oleh dewan 18 (Gam Raha dan Bobato Nyagimoi se Tufkange). Kekosongan itu berdampak pada merosotnya legitimasi kekuasaan elite Kesultanan Ternate akibat hilangnya kontrol politik dan birokrasi di wilayahnya. Kapasitas mereka hanya sebatas pelengkap struktur pemerintahan hingga berakhirnya pemerintahan Soekarno. Begitu terbatas dan lemahnya kekuasaan elite Kesultanan Ternate, sehingga nyaris tidak banyak yang bisa dilakukan. Hampir semua akses yang mengarah ke kepentingan kekuatan lokal, dipastikan terisolasi selama tak adanya sultan.

Oleh karena itu, untuk menjelaskan bagaimana strategi yang digunakan Sultan Iskandar Muhammad Djabir Sjah dalam upaya mempertahankan kekuasaannya pada pemerintah Soekarno, maka alur kajian akan dimulai dengan menelusuri terlebih dahulu bagaimana peta politik lokal pasca kemerdekaan Republik Indonesia. Selanjutnya menelusuri aktivitas pendidikan Iskandar Muhammad Djabir Sjah hingga dilantik menjadi Sultan Ternate ke-47dan Residen Maluku Utara pada 1945. Bagian selanjutnya akan memaparkan beberapa peristiwa politik seperti; keterlibatan Sultan Iskandar Muhammad Djabir Sjah dari konferensi Malino dan Denpasar, hingga terpilih menjadi Menteri Dalam Negeri Indonesia Timur pada 1949. Oleh karena itu, tulisan ini diharapkan mengambarkan secara rinci peristiwaperistiwa politik tersebut.

\section{METODE PENELITIAN}

Dalam penelitian ini, metode yang digunakan meliputi empat tahapan kerja yaitu; heuristik, kritik, interpretasi, dan penulisan (historiografi). Heuristik, adalah upaya penelusuran dan pengumpulan 
sumber-sumber masa lampau. Sumber yang dilakukan dalam penelitian ini terbagi dua, yaitu sumber tertulis dan lisan. Sumber tertulis diperoleh dari sejumlah perpustakaan. Selain sumber tertulis juga sumber lisan yang diperoleh dengan jalan melakukan interview mendalam (dept interview) terhadap para informan kunci (key informan), yakni para pelaku atau saksi sejarah yang masih hidup hingga saat ini. Pada tahap ini, dilakukan penelusuran para tokoh yang terlibat maupun saksi dalam perjuangan kemerdekaan RI 1945. Tokoh-tokoh ini menjadi perhatian dikarenakan untuk mengetahui secara detail dan juga tentang kejadian-kejadian terlupakan yang selama ini belum terungkap.

Setelah kedua jenis sumber diatas didapatkan, maka langkah selanjutnya adalah dengan melakukan kritik sumber. Kritik sumber mempunyai dua aspek yaitu kritik eksternal dan kritik internal. Metode ini dimaksudkan untuk memberi penilaian mengenai otentik dan kredibilitas sumber-sumber yang dipakai sebagai acuan. Penelitian ini akan lebih banyak menggunakan sumber-sumber surat kabar dan majalah. Dalam hubungan ini, tidak dapat dipungkiri bahwa setiap keterangan terkandung unsur subjektivitas. Sehingga dalam menganalisa sumber, hendaknya harus selalu bersikap hati-hati karena bagaimanapun bentuk laporan selalu mengandung unsur-unsur subjektivitas. Dengan demikian, selain mempertajam metodologi, juga dilakukan uji silang (cross cek) dengan sumber-sumber lisan dan tulisan.

Tahap ketiga adalah interpretasi. Bagian ini berarti menetapkan makna yang saling berkaitan dari fakta sejarah satu sama lain yang terdapat dalam sumber tertulis dan lisan. Dalam menginterpretasi dan menganalisis fakta, digunakan metode hermeneutik atau tafsir teks. Metode ini digunakan untuk menerjemahkan berbagai peristiwa yang terdokumentasi secara lebih mendalam dan menyeluruh menjadi satu kesatuan yang logis dan harmonis. Interpretasi terhadap sebuah teks dilakukan dengan menggunakan teori-teori dan konsep ilmu-ilmu politik agar dapat menjelaskan partisipasi masyarakat Maluku Utara dalam kemerdekaan Republik Indonesia 1945.

\section{HASIL DAN PEMBAHASAN}

\section{Konferensi Malino 16 Juli-24 1946: Embrio lahirnya NIT}

Berdasarkan restu yang diperoleh dari Pemerintah Belanda, maka van Mook menyelenggarakan Konferensi Malino 16-24 Juli 1946 di Makasar Sulawesi Selatan. Sulawesi Selatan dijadikan sebagai tempat penyelenggaraan Konferensi Malino oleh van Mook, disamping pertimbangan politik tentu sangat spekulatif dan konspiratif mengingat tempat ini secara geografis jauh dari jangkauan kekuasaan Pemerintah Republik Indonesia. Dengan memanfaatkan wilayah bagian Timur Indonesia yang diduduki Tentara Australia atas nama Sekutu, secara politik dan keamanan tentu menguntungkannya. Konferensi ini dihadiri 39 orang anggota senat dari 15 daerah seperti; Bali, Lombok, Riau, Sulawesi Selatan, Bangka Belitung, Borneo Barat, Borneo Timur, Maluku Utara, Minahasa, Sangir Talaud, Gorontalo, Sulawesi Tengah, Neuw Guinea (Irian), Flores, Timor, Sumba, Sumbawa, Borneo Selatan, dan Maluku Selatan, dengan tujuan membahas rencana pembentukan negara-negara bagian yang berbentuk federasi di Indonesia serta rencana pembentukan negara yang meliputi daerah-daerah di Indonesia bagian Timur.

Pada Konferensi Malino, van Mook menawarkan sistem susunan ketatanegaraan federasi, dengan syarat bahwa bagian-bagian yang akan merupakan komponen dari federasi itu haruslah merupakan wilayahwilayah yang luas dan mempunyai potensi ekonomi, sosial, dan politik yang kuat. Gagasan van Mook tersebut mendapat tanggapan yang positif dari delegasi Maluku Utara Sultan Ternate Iskandar Djabir Syah. Bagi Iskandar Muhammad Jabir Syah, pembentukan negara federal bukanlah disintegrasi tapi suatu sistem pemerintahan yang tidak berbeda dengan negara kesatuan. Ide dasar negara federal yang paling subtansial adalah terjaminnya keadilan dalam alokasi sumber daya, disamping itu memungkinkan manajemen adiministrasi menjadi lebih efektif dan efisien, karena lingkupnya lebih terbatas. Di samping itu Negara Indonesia Timur akan menjelma menjadi sebuah negara yang makmur dan dapat mengembangkan identitasnya sendiri, sebagimana diinginkan semua pihak.

Secara konseptual, gagasan van Mook tentang negara federal bukanlah hal yang baru bagi Iskandar Muhammad Jabir Syah. Konsep negara federal sesungguhnya tidak jauh berbeda dengan sistem 
pemerintahan yang dianut oleh Kesultanan Ternate. Dalam struktur kesultanan Ternate (Maloko Kie Raha), masing-masing kerajaan mengurus urusan dalam negerinya sendiri-sendiri. Sementara urusan keluar, khususnya militer dan keuangan, dibentuk oleh dewan delapan belas yang merupakan wakilwakil dari empat kerajaan yang terdiri dari wakil pemerintah dan wakil angkatan perang ditambah utusan daerah-daerah kerajaan. Dengan mendapat pengakuan dan jaminan dari van Mook, bahwa bentuk pemerintahan Republik Indonesia Serikat menjadi garansi dalam menata harmonisasi dan menjamin keadilan masyarakat. Sehingga pulau-pulau pinggiran dan daerah-daerah pedalaman yang jauh dari pusat dapat lebih bebas memekarkan diri. Disamping itu, dengan adanya konsep negara federal ini memberi ruang kepada para raja-raja di timur indonesia tetap berkuasa.

Konferensi Malino 16-24 Juli 1946 sebagai peletak dasar terbentuknya negara Indonesia Timur (NIT). NIT merupakan yang tertua dan terbesar di antara negara-negara yang dibentuk oleh pemerintah Hindia Belanda. Kuatnya kedudukan Belanda di Indonesia Timur menjadi alasan bagi Belanda untuk memberikan otonomi yang luas kepada Negara Indonesia Timur yang terdiri dari ratusan pulau besar dan kecil dan terbagi kedalam 13 daerah otonom. Indonesia Timur dipilih sebagai daerah tempat negara bagian pertama akan dibentuk. Kekuatan militer Belanda relatif besar di daerah ini, lagi pula Belanda benar dalam penilaiannya bahwa gagasan negara federal akan mempunyai daya tarik tersendiri bagi rakyat di luar Pulau Jawa yang sudah agak cemas akan dominasi politik oleh orang-orang Jawa, yang jumlahnya jauh lebih besar.

Dalam konferensi ini, beberapa keputusan yang hasilkan diantaranya; (1) Mengenai soal lagu kebangsaan dan bendera. Konferensi mengambil suatu keputusan bahwa lagu kebangsaan Indonesia Raya diterima sebagai lagu kebangsaan; (2) Dalam bidang politik dan ketatanegaraan, konferensi Malino memutuskan dengan suara bulat dalam bidang pembangunan kembali ketatanegaraan di wilayah Hindia Belanda, yakni pembentukan suatu federasi yang meliputi seluruh wilayah Hindia Belanda dulu bernama Negara Indonesia Serikat yang terdiri dari bagian-bagian (negara-negara) dengan daerah kekuasaan yang besar dan wewenang kekuasaan memerintah sendiri yang luas mungkin; (3) Hubungan dengan Belanda. Konferensi Malino menyatakan sebagai keyakinannya dianggap perlu untuk ditetapkan secara teliti kurun waktu yang dianggap perlu untuk mengadakan kerjasama di lingkungan kerajaan, yang dimaksudkan untuk memberi kesempatan kepada Negara Indonesia Serikat untuk mewujudkan organisasi dalam bidang ketatanegaraan, ekonomi, sosial dan kebudayaan, dan untuk memperoleh perlengkapan-perlengkapan yang akan memberi kemungkinan-kemungkinan kepada Negara Indonesia Serikat dengan segala kebebasan dan merdeka mengambil keputusan sendiri mengenai kelanjutan hubungan antara Belanda dan Indonesia.

Dengan demikian, Konferensi Malino merupakan awal diletakkannya dasar-dasar pemecahan wilayah Indonesia dalam daerah-daerah berdiri sendiri sebagai negara bagian dari suatu negara federal dan memberikan kemungkinan kepada pihak Belanda untuk menguasai Indonesia. Konferensi Malino merupakan langkah awal Belanda membentuk Negara Indonesia Serikat, berdasarkan konsep yang disodorkan van Mook, yaitu The federal commonwealth of Indonesia. Konferensi yang diselenggarakan kurang lebih 8 hari itu, akhirnya ditutup oleh Van Mook sebagai ketua konferensi dengan meminta peserta memberikan persetujuannya. Ia mengemukakan niatnya untuk membangun negara di Jawa, Sumatra, Kalimantan dan Timur Besar. Untuk pembentukan Negara Indonesia Timur akan dibicarakan khusus dalam konfrensi Denpasar dan dilakukan bersama-sama dengan ARC. Tujuannya agar aparat telah ada dipakai terus.

Gagasan untuk membentuk negara serikat (negara yang terdiri dari negara bagian) sebenarnya sudah direncanakan oleh van Mook sebelum kemerdekaan RI. Maka tidaklah mengherankan apabila tokohtokoh Republik yang sebagian besar merupakan pejuang pergerakan nasional menentang gagasan ini. Karena federalisme yang diinginkan oleh van Mook itu harus dipimpin oleh Belanda. Oleh karena itu, Konferensi Malino tidak mendapat sambutan yang baik dari kalangan Republik Indonesia. Konferensi Malino dianggap sebagai suatu usaha pihak Belanda untuk mendapatkan dukungan dari wakil-wakil daerah di luar Jawa sebagai strategi untuk memecah belah bangsa Indonesia. 


\section{Konferensi Denpasar 7-12 Desember 1946: Terbentuknya NIT}

Sesuai kesepakatan pada Konferensi Malino bahwa Konferensi kedua (sebagai kelanjutannya) akan diadakan kurang lebih empat bulan di Denpasar. Denpasar (Bali) di pilih sebagai tempat penyelenggaraan Konferensi karena tempatnya aman setelah perang Margarana. Konferensi Denpasar sebenarnya merupakan tindak lanjut dari Konferensi Malino untuk menyusun tata pemerintahan dan ketatanegaraan baru di wilayah timur besar melalui perundingan yang diprakarsai oleh van Mook. Oleh Audrey R. Kahin, Konferensi Denpasar merupakan embrio lahirnya NIT, yang merupakan prototipe negara-negara boneka yang kemudian secara terus-menerus di bentuk Belanda.

Sebelum dilaksanakannya Konferensi Denpasar pada tanggal 7-24 Desember 1946, pada tanggal 15 Nopember 1946 Pemerintah Belanda yang diwakili Schermerhorn dan Sutan Syahrir dari Indonesia menandatanggani persetujuan penyelesaian masalah Indonesia-Belanda yang disebut "Persetujuan Linggarjati" yang bersisi tentang; (1) Pemerintah RI dan Belanda bersama-sama menyelenggarakan berdirinya sebuah negara federal yang dinamakan Negara Indonesia Serikat (NIS); (2) NIS akan berkerjasama dengan pemerintah kerajaan Belanda untuk membentuk sebuah uni Indonesia Belanda.

Konferensi Denpasar berlangsung setelah persetujuan Linggarjati pada tanggal 15 Nopember 1946. Setelah naskah persetujuan disahkan pada tanggal 20 Desember 1946, maka van Mook dapat leluasa bertindak membentuk Negara Indonesia Timur yang tidak bertentangan dengan semangat dan jiwa persetujuan Linggarjati. Pihak peserta konferensi yang pro Republik pun ikut mendukung pembentukan Negara Indonesia Timur karena naskah persetujuan Linggarjati itu menegaskan bahwa "Pemerintah Belanda mengakui kenyataan kekuasaan de facto Pemerintah Republik Indonesia atas Jawa, Madura dan Sumatera. Adapun daerah-daerah yang diduduki oleh tentara Serikat atau tentara Belanda dengan berangsur-angsur dan dengan kerja bersama antara kedua belah pihak akan dimasukan pula di dalam atau ke dalam Daerah Republik.

Pada Konferensi Denpasar itu diikuti oleh 71 perwakilan dari seluruh daerah Indonesia Timur. Jumlah utusan-utusan daerah yang dipilih oleh masing masing daerah dan ditetapkan oleh van Mook yang terdiri dari 55 utusan daerah, kebanyakan diwakili oleh Raja ataupun Sultan dan 15 utusan dari golongan minoritas (Cina dan Timur Asing lainnya) sehingga berjumlah 71 orang peserta. Untuk wilayah Maluku Utara diwakili oleh Iskandar Djabir Syah (Sultan Ternate) dan Zainal Abidin Alting (Sultan Tidore). Konferensi ini mempunyai wewenang berdasarkan keputusan Konferensi Malino untuk menyusun tata pemerintahan dan ketatanegaraan baru di wilayah Timur Besar melalui perundinganperundingan dan pembicaraan-pembicaraan dengan wakil-wakil Pemerintah Belanda. Menurut Ide Anak Agung Gde Agung, antara Konferensi Malino dan Konferensi Denpasar terdapat perbedaan nyata. Dalam Konferensi Malino, pembicaraan-pembicaraan masih bersifat umum dan menyangkut masalah politik, ekonomi, sosial dan budaya di Indonesia pada umunya. Sementara dalam Konferensi Denpasar, pembicaraan telah dipusatkan pada satu masalah pokok, yaitu pembentukan susunan ketatanegaraan di wilayah Timur Besar, dimana sudah tersedia suatu kertas kerja berupa rencana peraturan pembentukan Negara Timur Besar yang disiapkan oleh Komisariat Umum untuk Kalimantan dan Timur Besar.

Pada konferensi itu, Sultan Ternate Iskandar Djabir Syah menentang kebijakan pemerintahan swapraja yang diberlakukan pemerintah Belanda sejak tahun 1938, dimana wakil-wakil Pemerintah Hindia Belanda seperti para kontrolir dan asisten residen diberi kekuasaan besar, sehingga raja hanya merupakan boneka saja. Iskandar Djabir Syah menyampaikan ketidakpuasannya mengenai posisi dan kedudukan para raja yang mengepalai pemerintahan swapraja. Menurutnya, posisi sebagai Sultan sering disepelekan. Segala keputusan yang dibuat harus bergantung pada persetujuan yang dikeluarkan oleh pihak Belanda. Hal ini membuat posisi Sultan hanya sebagai tempelan atau orang kedua, bahkan sering terjadi benturan kepentingan sehingga seolah-olah terdapat pemerintahan daerah secara dualisme. Hal itu sering membuat rakyatnya bingung. Sultan bagaikan boneka yang bisa dipermainkan oleh pihak Belanda, kedudukannya sebagai seorang Sultan sering terasa sulit, wibawanya sebagai seorang Sultan sering terabaikan demi kepentingan pihak Belanda. 
Oleh karena itu menurut Iskandar Djabir Syah agar sifat pemerintahan dualisme di daerah-daerah swapraja dihapuskan dan kepada raja sebagai kepala pemerintahan swapraja benar-benar diberikan kekuasaan dan wewenang yang nyata, sungguh-sungguh dan berwibawa. Pandangan yang sama juga disampaikan oleh L. Katoppo (utusan Minahasa), mengatakan bahwa Negara Indonesia Timur terdiri atas lebih dari $75 \%$ daerah swapraja dan 115 pemerintahan swapraja. Kedudukan para kepala pemerintahan swapraja itu diatur dengan apa yang dinamakan "korte verklaring" (pernyataan pendek) dan "lange kontrakten" (kontrak panjang). sebagai suatu pengakuan Pemerintah Hindia Belanda terhadap kedudukan istimewa para raja itu yang secara turun temurun memerintah suatu daerah swapraja.

Pada Konferensi Denpasar, Sultan Ternate Iskandar Djabir Syah menyetujui keputusan tentang negara federal, dan secara konsisten selalu mempertahankannya karena mirip dengan konsep dan paham Moloko Kie Raha yang selama ini dianutnya. Menurutnya, situasi sosiologis-antropologis bangsa Indonesia yang bersifat jamak-majemuk maka konsep federasi-lah yang cocok untuk bangsa Indonesia. Dalam Konferensi tersebut, van Mook memaksakan ide federalismenya. Apa yang dilakukan tanpa kerjasama dengan pihak Republik Indonesia seperti disetujuinya dalam perjanjian Linggarjati. Negara Indonesia Timur ini sangat strategis bagi van Mook dalam mencapai cita-citanya menciptakan suatu Negara Republik Indonesia Serikat yang masih tetap dalam lingkungan kerajaan Belanda.

Terbentuknya Negara Indonesia Timur (NIT), menurut Van Mook bahwa Indonesia Timur akan dapat menjelma menjadi suatu negara yang mempunyai daya hidup yang kuat dan akan dapat mengembangkan identitasnva sendiri sehingga akan berhasil merupakan suatu bagian yang berharga dari federasi Indonesia yang akan diwujudkan sebagaimana yang diinginkan semua pihak. Pada akhir Konferensi Denpasar 24 Desember 1946, terbentuklah negara baru yang dinamakan Negara Indonesia Timur dalam wadah Negara Republik Indonesia Serikat ( RIS) meliputi wilayah Sulawesi, Sunda Kecil (Bali dan Nusa Tenggara) dan Kepulauan Maluku.

Konferensi Denpasar itu terpilih Cokorda Gde Raka Sukawati sebagai Kepala Negara Indonesia Timur pertama. Perdana Menteri adalah Nadjamoedin Daeng Malewa yang merangkap sebagai Menteri Perekonomian, dan ketua DPRS terpilih Mr. Tadjoeddin Noer. Hanya kaum republikan berpendapat bahwa pembentukan Negara Indonesia Timur dalam rangka pembentukan Negara Republik Indonesia Serikat hanya merupakan satu tahap dalam proses perjuangan menuju Negara Republik Indonesia sesuai dengan semangat proklamasi 1945. Sementara mereka yang mendukung federalisme, memang menganggap Negara Indonesia Timur sebagai tujuan dalam rangka pembentukan Negara Federal yang tetap berada dalam lingkungan kerajaan Belanda.

\section{Menjadi Menteri Dalam Negeri NIT}

Sejak awal pembentukan Negara Indonesia Timur yang digagas oleh van Mook atas nama Pemerintah Belanda, Iskandar Djabir Syah telah menunjukan partisipasinya sebagai anggota NIT mewakili Maluku Utara. Partisipasinya sungguh beralasan karena dari aspek sejarah dan politik Kesultanan Ternate memiliki kedekatan dengan Pemerintah Belanda yang telah lama bercokol di Pulau Ternate hingga Perang Dunia ke II, bahkan pada saat Jepang menduduki Pulau Ternate, Iskandar Djabir Syah bersama keluarganya diungsikan ke Brisbane Australia pada September 1945. Setelah kepulangannya dari Australia, Iskandar Djabir Syah diangkat sebagai kepala daerah (residen) dengan pangkat Kolonel Tituler der Koninghen Orange van Nasau.

Selama menjadi anggota senat NIT mewakili Maluku Utara, Iskandar Djabir Syah selalu gigih memperjuangkan konsep negara federal dalam konferensi Malino dan Denpasar. Dengan alasan itulah, maka pada Kabinet Tatengkeng, Iskandar Djabir Syah diangkat menjadi Menteri Dalam Negeri NIT (27 Desember 1949-14 Maret 1950). Setelah dilantik oleh Presiden Negara Indonesia Timur (NIT), Tjokorde Gde Rake Soekawati pada tanggal 27 Desember 1949, Iskandar Djabir Syah mulai menjalankan tugasnya sebagai menteri dalam negeri. Kedudukannya sebagai Menteri Urusan Dalam 
Negeri, Iskandar Djabir Syah telah berhasil melimpahkan kekuasaan pemerintah pusat kepada kepalakepala daerah di seluruh wilayah Negara Indonesia Timur.

Kabinet J.E Tatengkeng merupakan kabinet darurat atau pemerintahan peralihan dan masa kepemimpinannya hanya satu tahun.Walaupun demikian, Kabinet Tatengkeng bertekad untuk menyusun tertib hukum baru dengan pembentukan susunan ketatanegaraan di Negara Indonesia Timur sedemikian rupa sehingga dari tingkat bawah sampai susunan teratas dapat diwujudkan suatu bentuk pemerintahan yang demokratis dan bercorak kebangsaan sesuai dengan azas federalisme. Pembentukan daerah-daerah dengan otonomi yang luas dan kekuasaan serta wewenang yang mantap dimana pemerintah swapraja memainkan peranan yang penting didampingi oleh dewan yang dipilih oleh rakyat. Berdasarkan atas azas demokrasi dan dengan berpegang teguh bahwa Negara Indonesia Timur adalah suatu negara hukum di mana ketertiban dan keamanan terjamin sehingga rakyat merasa dirinya dilindungi oleh hukum sehingga dapat hidup aman dan tenteram. Kabinet Tatengkeng menjalankan kebijaksanaan yang bersifat dwi-fungsi yang satu dengan yang lain mempunyai keseimbangan yang harmonis.

Pada era kabinet Tatengkeng telah muncul benih-benih pemberontakan yang ingin melepaskan diri dari Negara Indonesia Serikat dan bergabung dengan RI. Pertikaian antara APRIS dan TNI itu mendorong sejumlah daerah otonom di wilayah NIT tampil memproklamasikan daerahnya keluar dai NIT dan menggabungkan daerahnya menjadi bagian dari RI dengan kedudukan sebagai suatu provinsi. Misalnya pada tanggal 26 April 1950, Andi Idjo Karaeng (Sulawesi Selatan), memproklamirkan Sulawesi Selatan menjadi satu bagian provinsi RI. Hal yang sama juga dilakukan pula oleh Adjuba Wartabone untuk daerah Sulawesi Utara.

Pergolakan dan pertentangan antara golongan federalis dan unitaris di Sulawesi Selatan dan terutama di Makasar berkobar dengan hebat sehingga timbul suasana yang sangat gawat. Dari golongan unitaris yang dipelopori oleh anggota-anggota parlemen Fraksi Kesatuan Nasional Indonesia, mendesak kepada pemerintah untuk diijinkan mengadakan demonstrasi secara besar-besaran dengan tujuan agar Negara Indonesia Timur segera di bubarkan dan dimasukan kedalam daerah kekuasaan Republik Indonesia.

Di samping itu pemberontakan Andi Aziz di Makasar awal April 1950 mengakibatkan terjadinya krisis Kabinet NIT. Pada tanggal 20 April tokoh Pemuda Indonesia Maluku (PIM), Pupella, mengajukan mosi tidak percaya dalam parlemen NIT. Akibatnya, Perdana Menteri Tatengkeng mengundurkan diri dan kabinet bubar. Dengan demikian, Kabinet J.E Tatengkeng tidak berusia panjang. Program kerjanya hanyalah mengatasi masa peralihan menuju terbentuknya Negara kesatuan sebagai hasil peleburan RIS dan Negara RI. Perkembangan demikian tentunya mempengaruhi suasana politik di Negara Indonesia Timur dan memberi dorongan besar kepada golongan unitaris untuk mewujudkan tujuannya yakni membubarkan Negara Indonesia Timur.

Bubarnya Negara Indonesia Timur pada tanggal 15 Agustus 1950 menimbulkan keheranan di banyak kalangan tentang cepatnya sistem federasi terhapus dari Indonesia. Kurang lebih enam bulan sesudah penyerahan kedaulatan kepada pemerintah Republik Indonesia Serikat bentuk Negara sudah berubah menjadi suatu Negara kesatuan. Perubahan bentuk kenegaraan tersebut terutama di kalangan Pemerintah Belanda perubahan asas Negara tersebut meninggalkan kesan yang sangat mendalam. Pemerintah Hindia Belanda menuduh pihak Indonesia tidak jujur dalam pelaksanaan Konferensi Meja Bundar dan berhubung dengan itu menyatakan kekecewaannya.

Sikap Pemerintah Belanda menjelma menjadi sikap anti Pemerintah Indonesia teraktualisasi dalam kebijakan luar negerinya yang secara gigih menentang Indonesia dalam masalah Irian Barat di tahun 1960-an. Ketika Perdana Menteri W. Drees kembali terpilih yang keempat (1956-1958), dialah yang menjadi pendorong utama untuk memasukkan Irian Barat (sekarang Papua) dalam wilayah Kerajaan Belanda pada waktu diadakan perubahan Undang-Undang Dasar Kerajaan Belanda di tahun 1956. 


\section{Bubarnya RIS dan Akhir Karier Politik Iskandar Djabir Syah}

Sejarah mencatat setelah bubarnya Negara Indonesia Serikat (RIS) dan kembali menjadi Negara Kesatuan RI pada tahun 1950. Sultan Iskandar Djabir Syah dipindahkan ke Jakarta oleh pemerintahan Soekarno karena dituduh merupakan salah satu tokoh federalis selain itu dituduh sebagai tokoh yang pro RMS dan membuat makar kepada Pemerintah Republik Indonesia. Selama di Jakarta, Iskandar Djabir Syah ditempatkan sebagai salah satu staf di departemen dalam negeri pada tahun 1951 hingga 1971. Dalam periode tersebut Kesultanan Ternate mengalami kekosongan pemerintahan. Seluruh kegiatan dan pelaksanaan pemerintahan di jalankan oleh lembaga legislatif atau dewan delapan belas (bobato nyagimo setofkange). Kekosongan itu berdampak pada merosotnya kekuasaan elite istana (bangsawan) akibat hilangnya kontrol politik dan birokrasi di wilayahnya. Hampir semua akses yang mengarah pada kepentingan kekuatan lokal dipastikan terisolasi semuanya, pada saat ketiadaan sultan. Dengan demikian wilayah kekuasaan bobato nyagimoi se tufkange hanya terbatas pada tembok-tembok istana. Kapasitas mereka hanya sebatas pelengkap strukutur pemerintahan. Hal ini disebabkan oleh otoritas kepemimpinan yang berada ditangan sultan. Walaupun masih memiliki birokrasi pemerintahan itupun hanya mengurusi kepentingan-kepentingan rumah tangga istana.

Pada saat yang sama, beberapa kebijakan pemerintah Soekarno mengeluarkan sejumlah aturan dalam membatasi ruang gerak para penguasa lokal. Misalnya, pembubabaran dewan raja-raja pada tahun 1950 . Contoh lain adalah UU Pokok Agraria 1960 tentang pembatasan dan kepemilikan tanah (pengambil alihan oleh negara terhadap tanah-tanah swapraja), serta pembentukan pemerintahan daerah swatantra tingkat 1 Maluku, berdasarkan UU No 60 tahun 1958, dengan menetapkan Ambon sebagai Ibukota propinsi Maluku. Sebagai penguasa di tingkat II (Bupati) tidak lagi harus dijabat oleh sultan dan keluarganya.Sehingga dalam perkembangan selanjutnya jabatan-jabatan publik lebih didominasi oleh kelompok non kesultanan. Akhirnya status Ternate sebagai kotapraja dibubarkan dan direduksi menjadi sebuah kabupaten tingkat II yang memiliki keterbatasan otoritas pemerintahan.

Beberapa kebijakan Soekarno tersebut sangat menekan kekuasaan elite Kesultanan Ternate, sehingga nyaris tidak bisa berbuat banyak, karena hampir semua akses yang mengarah pada kepentingan kekuatan lokal hampir dipastikan semuanya terisolasi oleh bentuk-bentuk kekuasaannya. Bahkan segala aktifitas yang dilakukan hanya bersifat seremonial sehingga kekuatan dan pengaruh juga ikut terpangkas. Begitu kuatnya intervensi negara terhadap kekuasaan tradisonal pada era kekuasan Soekarno, sehingga keraton mengalami kemerosotan legitimasi.

Setelah pensiun dari dinas kementerian dalam negeri pada 1969, sisa hidup Sultan Iskandar Djabir Syah dihabisakannya di Jakarta. Pada tanggal 4 Juli 1975 Sultan Iskandar Djabir Syah meninggal dalam usia ke 75 tahun dan dimakamkan di pemakaman umum Pekuburan Karet. Terlepas sebagi tokoh federalis yang mendukung pembentukan Negara Indonesia Timur dalam wadah Negara Indonesia Serikat.Salah satu jasa besar dari Iskandar Djabir Syah adalah mengembalikan status Kesultanan Ternate dari afdeling (setingkat kecamatan) menjadi Karesidenan (setingkat propinsi) dengan pangkat Kolonel Tituler der Koninghen Orange van Nasau. Dengan jabatan inilah Sultan Iskandar Djabir dipandang oleh rakyat sebagai Raja Besar di wilayah Moloku Kie Raha.

\section{KESIMPULAN}

Sejarah menunjukan partisipasi politik elite Kesultanan Ternate dalam negara kesatuan telah dimulai sejak awal kemerdekaan Republik Indonesia, ditandai dengan berdirinya Negara Indonesia Timur (NIT), pada tanggal 24 Desember 1946. Terbentuknya Negara Indonesia Timur kemudian menjadi inspirasi politik bagi Sultan Iskandar Muhammad Jabir Syah (Sultan Ternate ke-47), untuk melibatkan diri sebagai anggota senat NIT mewakili Maluku Utara, dengan mengikuti konperensi Malino dan Denpasar sebagai anggota senat mewakili Maluku Utara sekaligus merupakan salah satu desainernya. Sebagai tokoh federalis yang memperjuangankan pembentukan Negara Indonesia Timur dari konferensi Malino hingga Denpasar, maka dalam perkembangannya pada tahun 1949, Iskandar Jabir Syah diangkat menjadi Menteri Dalam Negeri NIT pada kabinet J.E. Tatengkeng (27 Desember 1947-14 Maret 1950). 
Realitas politik menunjukan, tatkala rezim Soekarno berkuasa, elite Kesultanan Ternate mengalami pembatasan. Pilihan politik Sultan Ternate ke-47 Iskandar Djabir Syah (1929-1975), dalam mendukung pembentukan Negara Indonesia Timur (NIT) yang diprakarsai oleh Herbertus J. van Mook pada 1946, berimplikasi diasingkannya ke Jakarta pada 1950, karena dituduh sebagai tokoh federalis. Perbedaan persepsi mengenai bentuk dan sistem pemerintahan Indonesia pasca kemerdekaan inilah, mendorong elite kesultanan tidak mendukung partai pemerintah Soekarno pada pemilu 1955. Pilihan politik tersebut tentu tidak menguntungkan posisi mereka, karena harus menghadapi, tidak hanya rival politik lokal, namun juga kekuatan nasional.

Selama pemerintahan Soekarno, elite Kesultanan mengalami krisis politik. Sikap konfrontatif mereka dengan tidak mendukung Negara Kesatuan Republik Indonesia (RI) dan partai pemerintah (PNI), menimbulkan pertanyaan, mengapa Presiden Soekarno tidak menghancurkan eksistensi politik mereka dalam ranah politik lokal di Ternate. Apakah beberapa kebijakan tersebut diatas, berpengaruh terhadap eksitensi politik mereka di Ternate atau sebaliknya. Faktanya, walaupun eksistensi politik mereka mendapatkan pembatasan. Namun secara kultural, tidak berdampak pada merosotnya kekuasaan elite kesultanan. Salah satu nilai yang mengakar kuat dalam masyarakat Ternate adalah menjunjung tinggi perkataan atau perintah sultannya dengan semboyan 'jou kasa ngom kage' ('dimana ada sultan disitulah kami').

\section{DAFTAR PUSTAKA}

Adnan, Amal. (2007). Kepulauan Rempah-Rempah: Perjalanan Sejarah Maluku Utara 1250-1950. Jakarta: Gora Pustaka Indonesia.

Arnold, Mononutu. (1981). Potret Seorang Patriot, Jakarta: Gunung Agung,

Arthur, A. Schillers. (1989). The Formation of Federal Indonesia 1945-1949. Bandung.

Audrey, Kahin. (1990). Pergolakan Daerah Pada Awal Kemerdekaan.Jakarta: Grafiti.

Chasan, Bousoiri. (Tanpa Tahun). Sekulimit Derita Satu Edisi Kehidupan Seorang Dokter, Jakarta.

F.S.A. de Clercq. (2007). Ternate:Karesidenan dan Kesultanan.Terjemahan Noer Fitriyanti dari,Bijdragen tot de kennis der Residentie Ternate, 1890. Ternate: Komunitas Uma Sania.

Herry, R.D. Nachrawy. (2003). Peranan Ternate Tidore Dalam Pembebasan Irian Barat. Ternate, Yayasan KieRaha.

Ide Anak Agung GdeAgung, (1985). Negara Indonesia Timur ke Republik Indonesia Serikat. Yogyakarta: Gadjah Mada.

Irza, Arnita Djafaar. (2005). Dari Moloku Kie Raha Ke Negara Federal: Biografi Sultan Iskandar Muhammad Jabir Syah. Jakarta: Bio Pustaka.

L. Katoppo. (1972). Perdjoeangan Irian Kembali ke Dalam Wilayah RI. Bandung: Kilat Madju.

Leonard Y. Andaya. (1993). The World of Maluku: Eastern Indonesia in the Early Modern Period. Honolulu: University of Hawaii Press.

Sutrisno, Kutoyo. (1978). Sejarah Kebangkitan Nasional Daerah Maluku. Jakarta: Proyek Penelitian dan Pencatatan Kebudayaan Daerah Departemen Pendidikan dan Kebudayaan RI.

Syahril, Muhammad. (2006). Kesultanan Ternate: Sejarah Sosial Ekonomi \& Politik. Yogyakarta: Ombak. 